\title{
Synthesis and Anti-tumor Activity of a Fluorinated Analog of Medroxyprogesterone Acetate (MPA), $9 \alpha$-Fluoromedroxyprogesterone Acetate (FMPA)
}

\author{
Natsuko Murata, ${ }^{*, a}$ Shiho Fujimori, ${ }^{a}$ Yoshitatsu Ichinara, ${ }^{a}$ Yoshio SAto,${ }^{b}$ Taketo YamaJI, ${ }^{b}$ \\ Hiroshi Tsubor, ${ }^{b}$ Masayuki Uchida, ${ }^{b}$ Hiroto Suzuki, ${ }^{a}$ Masashi Yamada, ${ }^{a}$ Tsutomu Oikawa, \\ Hideo Nemoto, ${ }^{d}$ Junko Nobuhiro, ${ }^{e}$ Tominari Choshi, ${ }^{e}$ and Satoshi Hibino ${ }^{e}$ \\ ${ }^{a}$ Pharmaceuticals Development Department, Meiji Dairies Corporation; 1-2-10 Shinsuna, Koto-ku, Tokyo 136-8908, \\ Japan: ${ }^{b}$ Division of Research and Development, Meiji Dairies Corporation; 540 Naruda, Odawara, Kanagawa 250-0862, \\ Japan: ${ }^{c}$ Faculty of Health and Social Work, Kanagawa University of Human Services; 1-10-1 Heiseicho, Yokosuka, \\ Kanagawa 238-8522, Japan: 'Faculty of Pharmaceutical Sciences, University of Toyama; 2630 Sugitani, Toyama \\ 930-0194, Japan: and ${ }^{e}$ Faculty of Pharmacy and Pharmaceutical Sciences, Fukuyama University; 1 Sanzo, Gakuen-cho, \\ Fukuyama, Hiroshima 729-0292, Japan.
}

Received June 30, 2006; accepted August 8, 2006; published online August 18, 2006

\begin{abstract}
We synthesized $9 \alpha$-fluoromedroxyprogesterone acetate (FMPA) in order to test whether it is a more potent anti-angiogenic agent than medroxyprogesterone acetate (MPA), which has been widely used as a therapeutic agent for breast and endometrium cancers. FMPA was previously synthesized in 10 steps (total yield: $1 \%$ ). An efficient synthesis of FMPA has been achieved in 6 steps (total yield: 12\%). We examined the anti-tumor effect of FMPA, complexed with dimethyl- $\beta$-cyclodextrin (DM- $\beta$-CyD), on rat mammary carcinomas induced by 7,12 -dimethylbenz $[a]$ anthracene (DMBA). FMPA showed great anti-tumor effect on DMBA-induced rat mammary carcinomas.
\end{abstract}

Key words $9 \alpha$-fluoromedroxyprogesterone acetate; synthesis; medroxyprogesterone acetate; anti-angiogenic agent; dimethylbenz $[a]$ anthracene; mammary carcinoma

Neovascularization is involved in tumor growth as well as rheumatoid arthritis, diabetic retinopathy and age-related macular degeneration (AMD). ${ }^{1,2)}$ Tumor growth is often accompanied by angiogenesis, the resulting blood vessels supplying nutrients necessary to tumor cells. The development of new blood vessels is also a crucial step in the invasion and metastases of cancer cells of breast cancer, melanoma, lung cancer, prostate cancer and other cancers. ${ }^{3)}$ Thus, discovery of drugs which suppress angiogenesis has become one of the major focuses in cancer research. Angiostatin and endostatin, which are recombinant proteins, could be such drugs, but research on low-molecular inhibitors is still being vigorously studied in pharmaceutical industry.

As part of a research program to find novel anti-angiogenic drug candidates, we synthesized $9 \alpha$-fluoromedroxyprogesterone acetate (FMPA, $17 \alpha$-acetoxy-9 $\alpha$-fluoro- $6 \alpha$ methylprogesterone) (1) (Fig. 1). ${ }^{4}$ FMPA (1) is a fluorinated analog of medroxyprogesterone acetate (MPA) (2) (Fig. 1), which is widely used as a therapeutic agent for breast and endometrium cancer and possesses anti-angiogenic activity.

FMPA (1) exhibited an in vitro anti-angiogenic activity 100 times as strong as MPA (2) in a chorioallantoic membrane (CAM) assay system ${ }^{4}$ and exhibited a 7-fold stronger anti-angiogenic effect than MPA in a rabbit corneal assay

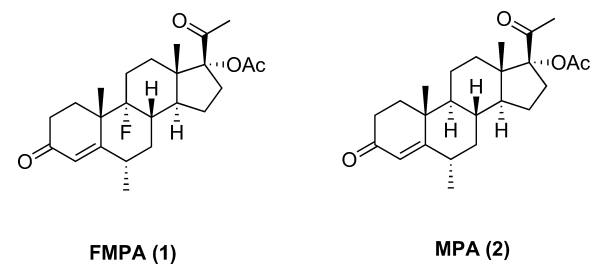

Fig. 1. The Chemical Structure of FMPA and MPA system. $^{5)}$ In addition, FMPA (1), complexed with $\gamma$-cyclodextrin $(\gamma-\mathrm{CyD})$, has shown anti-tumor effect on rat mammary carcinomas induced by 7,12-dimethylbenz $[a]$ anthracene (DMBA) which is greater than the effect of the parent compound, MPA (2). ${ }^{5)}$ FMPA (1) inhibits the activity of plasminogen activator (PA), an important protease playing an essential role in the process of angiogenesis, in bovine endothelial cells. $\left.{ }^{6}\right)$ However, further biological evaluations such as in vitro anti-tumor tests have been difficult, because the first synthesis method of FMPA (1) developed had low overall yield (1\%) and required many steps (10 steps). To overcome these problems, a practical synthetic route to FMPA (1) which involves six-steps and has $12 \%$ overall yield has been newly established. We here describe the full details of both the synthesis of FMPA (1) and its anti-tumor effect on rat mammary carcinoma when complexed with dimethyl- $\beta$ cyclodextrin (DM- $\beta$-CyD).

\section{Results and Discussion}

For the synthesis of $9 \alpha$-fluoro-MPA, FMPA (1), we utilized the $11 \beta$-hydroxy group of the steroid nucleus to introduce a fluorine atom at the $9 \alpha$-position on both routes (Charts 1,2). The initial route to 1 as shown in Chart 1 uses the commercially available $11 \beta$-17 $\alpha$-dihydroxy-4-pregnen3,10 -dione (3) as a starting material. Here, acetylation of the $11 \beta$-hydroxy group of $3(100 \%)$ gave the compound 4 . Sequential, acetalization and treatment with $m$-chloroperbenzoic acid $(m \mathrm{CPBA})$ afforded the epoxide $\mathbf{6}$, which was reacted with $\mathrm{CH}_{3} \mathrm{MgBr}$ to yield the 5-hydroxy-6-methylpregnene 7. Treatment of 7 with $5 \% \mathrm{KHSO}_{4}$ followed by treatment with $0.05 \mathrm{~N} \mathrm{NaOH}$ afforded the 6-methylpregnene 9 (23\% yield from 4 ). The fluorination of the $9 \alpha$-position of 9 was carried out by $70 \% \mathrm{HF}$ in pyridine ${ }^{7)}$ to produce the $9 \alpha$ - 

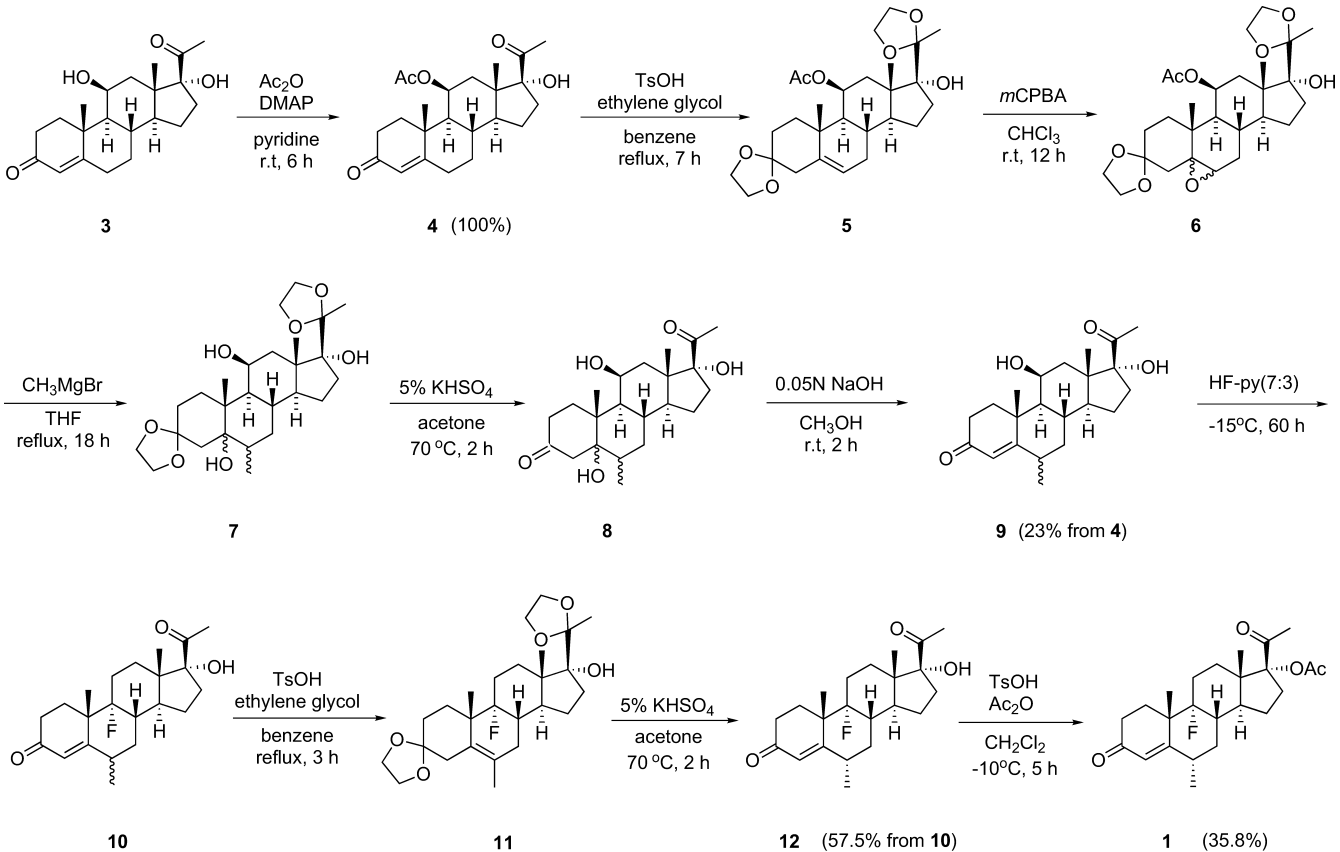

Chart 1
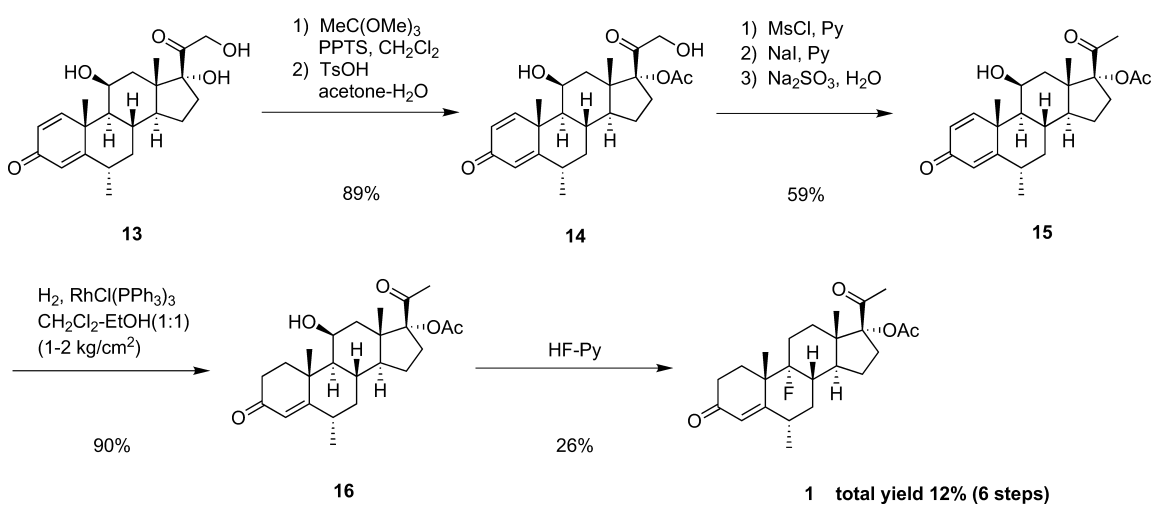

Chart 2

fluoroprogesterone 10 (23\%). The 6-methylprogesterone 10 was converted into $6 \alpha$-methylprogesterone 12 by acetalization followed by deacetalization in the usual manner ${ }^{8)}(58 \%$ yield from 10). Finally, acetylation of $\mathbf{1 2}$ by the mixed anhydride method $^{9)}$ provided $9 \alpha$-fluoromedroxyprogesterone acetate (1) (FMPA) (36\%). The overall yield of the initial synthetic route was a quite low $(1 \%)$ in a ten-step sequence.

On the other hand, our improved synthesis of FMPA (1) (Chart 2) was carried out starting from $6 \alpha$-methylpredonisolone 13, which is a cheaper starting material than $11 \beta, 17 \alpha$-dihydroxy-4-pregnen-3,10-dione 3. Specifically, acetylation of 13 was performed with trimethylorthoacetate, and then the resulting ortho ester was hydrolyzed to give $6 \alpha$ methylpredonisolone $17 \alpha-O$-acetate 14 (89\%). The hydroxyl group at the C-21 position of $\mathbf{1 4}$ was converted into the mesylate, followed by treatment with sodium iodide to yield pregnadiene-3,20-dione 15 (59\%). Reduction of 15 with hydrogen atmosphere in the presence of chlorotris(triphenylphosphine)rhodium(I) ${ }^{10)}$ provided $11 \beta$-hydroxy-pregnene3,20-dione $16(90 \%)$. Fluorination of $\mathbf{1 6}$ was performed using hydrogen fluoride in pyridine to produce FMPA (1) $(26 \%)$. The structure of 1 was confirmed by spectroscopy.
Thus, we succeeded in an efficient and practical synthesis of FMPA (1) with $12 \%$ overall yield in 6 steps.

FMPA (1) showed significant inhibitory effects on the growth of DMBA-induced rat mammary carcinomas at doses of 30 and $120 \mathrm{mg} / \mathrm{kg}$ as compared with a control group during the treatment and withdrawal periods (Fig. 2). The number of tumors which appeared after treatment was also significantly inhibited by FMPA (1) doses of 30 and $120 \mathrm{mg} / \mathrm{kg}$ as compared with the control group (Fig. 3). It has been reported that FMPA (1) complexed with $\gamma$-CyD showed antitumor effect on DMBA-induced rat mammary carcinomas, and its effect is greater than that of the parent compound, MPA (2). ${ }^{5}$ The bioavailability of FMPA (1) complexed with $\gamma$-CyD was found to be about 6 times higher than that of FMPA (1) suspended in carboxymethyl cellulose sodium salt and orally administered to rats. ${ }^{11)}$ In a preliminary study of pharmacokinetics of FMPA (1) in rats, DM- $\beta$-CyD complex exhibited bioavailability about 2 times higher than $\gamma$-CyD complex (unpublished data), so we used FMPA (1) complexed with DM- $\beta$-CyD in this study. As a result, FMPA (1) exhibited strong anti-tumor activity on DMBA-induced rat mammary carcinomas. Therefore, it is suggested that oral ad- 


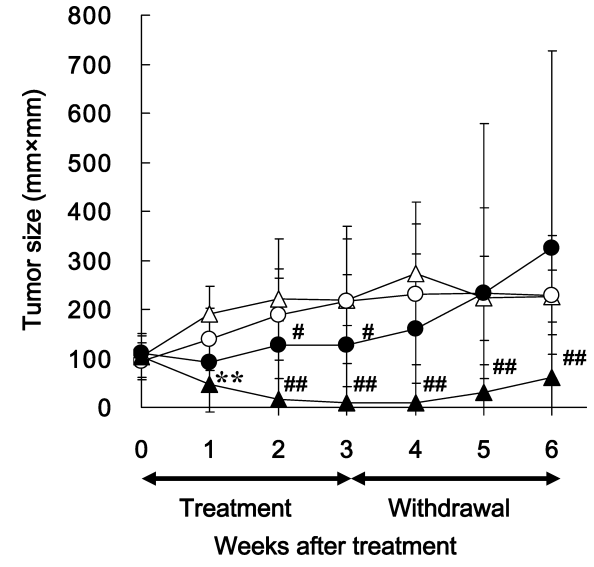

Fig. 2. Effect of FMPA on DMBA-Induced Mammary Tumor Size in Rats

Values represents the mean \pm S.D. of seven to 14 tumors per group. Each group consisted of seven to eight rats. $(\triangle)$ Distilled Water, $(O)$ Control (DM- $\beta$-CyD), $(\bullet)$ FMPA $30 \mathrm{mg} / \mathrm{kg}$, (ム) FMPA $120 \mathrm{mg} / \mathrm{kg}$. ** Significant difference from control $(p<0.01$, Dunnett multiple comparison test). \#,\# Significant difference from control $(p<0.05$, $p<0.01$, nonparametric Dunnett multiple comparison test)

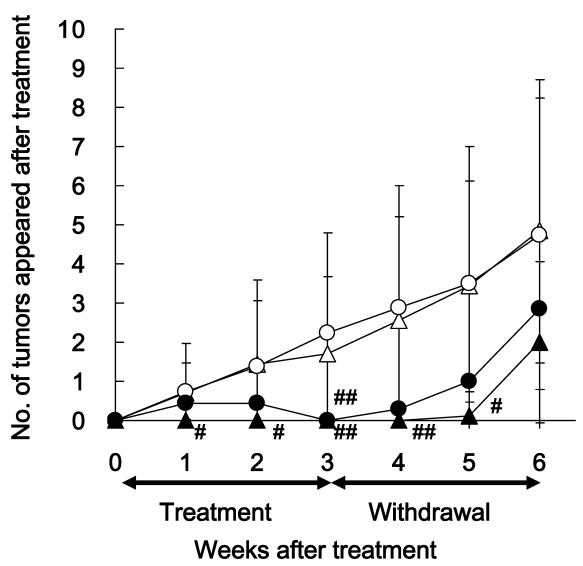

Fig. 3. Effect of FMPA on the Number of Tumors (Length $\geqq 5 \mathrm{~mm}$ ) Which Appeared after Treatment of Rats with DMBA-Induced Mammary Cancer

Values represents the mean \pm S.D. of seven to eight rats per group. $(\triangle)$ Distilled Water, (○) Control (DM- $\beta$-CyD), (@) FMPA $30 \mathrm{mg} / \mathrm{kg},(\boldsymbol{\Delta})$ FMPA $120 \mathrm{mg} / \mathrm{kg}$. \#, \# Significant difference from control $(p<0.05, p<0.01$, nonparametric Dunnett multiple comparison test).

ministration of FMPA (1) may be useful for treatment of mammary cancer.

\section{Conclusions}

In a preliminary work, ${ }^{4)}$ we proposed the anti-angiogenic effect of MPA (2) might be increased by giving it a fluorine atom at the $\mathrm{C}-9 \alpha$ position, a novel design. Based on this hypothesis, two synthetic routes of FMPA (1) were found. The newer synthetic route is a practical process using a cheaper starting material. Subsequently, potent anti-angiogenic effects have been verified for the FMPA (1) in several bioassay systems. ${ }^{4-6)}$ This study also indicates that FMPA (1) has strong anti-tumor activity, so that FMPA (1) may well be a useful oral drug for the treatment of human breast and endometrium cancer.

\section{Experimental}

General Melting points were measured on a Yanagimoto micro-melting point apparatus MP-500D and were uncorrected. Proton nuclear magnetic resonance spectra $\left({ }^{1} \mathrm{H}-\mathrm{NMR}\right)$ were taken with a Varian Unity-500 instrument using tetramethylsilane as an internal standard. Mass spectra (MS) were de- termined by a Shimadzu QP5050 mass spectrometer. Elemental analysis was done by Yanaco CHN CORDER MT-6.

$11 \beta$-Acetoxy-17 $\alpha$-hydroxy-4-pregnene-3,20-dione (4) A mixture of 4pregnene- $11 \beta, 17 \alpha$-diol-3,20-dione $3(2 \mathrm{~g}, 5.77 \mathrm{mmol}), \mathrm{Ac}_{2} \mathrm{O}(10 \mathrm{ml})$, pyridine $(20 \mathrm{ml})$ and 4-dimethylaminopyridine (DMAP) $(20 \mathrm{mg}, 0.16 \mathrm{mmol})$ was stirred for $6 \mathrm{~h}$ at room temperature. The reaction mixture was diluted with water $(50 \mathrm{ml})$ and extracted with $\mathrm{CHCl}_{3}$. The $\mathrm{CHCl}_{3}$ layer was sequentially washed with $10 \% \mathrm{HCl}$, a $5 \%$ aqueous $\mathrm{NaHCO}_{3}$ solution, and brine, dried over $\mathrm{Na}_{2} \mathrm{SO}_{4}$, and concentrated under reduced pressure. The residue was subjected to column chromatography (silica gel, $150 \mathrm{~g}$ ) using $70 \%$ $\mathrm{CHCl}_{3}$ /hexane as eluant to give the acetylated derivative $4(2.24 \mathrm{~g}, 100 \%)$ $\mathrm{mp} 159.5-160{ }^{\circ} \mathrm{C}(\mathrm{EtOAc} /$ hexane $) .{ }^{1} \mathrm{H}-\mathrm{NMR}\left(\mathrm{CDCl}_{3}\right): \delta 0.85(3 \mathrm{H}, \mathrm{s}), 2.01$ $(3 \mathrm{H}, \mathrm{s}), 2.21(3 \mathrm{H}, \mathrm{s}), 3.04(2 \mathrm{H}, \mathrm{m}), 5.34-5.56(1 \mathrm{H}, \mathrm{m}), 5.65(1 \mathrm{H}, \mathrm{s}) . \mathrm{MS}$ $m / z$ : $388\left(\mathrm{M}^{+}\right)$. Anal. Calcd for $\mathrm{C}_{23} \mathrm{H}_{32} \mathrm{O}_{5}: \mathrm{C}, 71.10 ; \mathrm{H}$ 8.30. Found: $\mathrm{C}$, $71.08 ; \mathrm{H} 8.50$.

6-Methyl-4-pregnene-11 $\beta, 17 \alpha$-diol-3,20-dione (9) 11-Acetate 4 (2 g, $5.15 \mathrm{mmol})$, ethylene glycol $(1.1 \mathrm{~g}, 17.7 \mathrm{mmol})$, and $p$-TsOH $(40 \mathrm{mg}$, $0.21 \mathrm{mmol}$ ) were refluxed in benzene $(100 \mathrm{ml})$ for $7 \mathrm{~h}$ while reducing humidity (by the use of a reflux condenser equipped with a moisture separator) After the reaction temperature lowered to room temperature, the mixture was washed with brine, dried over $\mathrm{Na}_{2} \mathrm{SO}_{4}$, and concentrated. The residue was used directly in the next step without further purification. $70 \% m \mathrm{CPBA}(2 \mathrm{~g}$, $8.11 \mathrm{mmol})$ was added to the residue $\mathbf{5}(2 \mathrm{~g}, 4.20 \mathrm{mmol})$ in $\mathrm{CHCl}_{3}(150 \mathrm{ml})$, and the mixture was stirred for $12 \mathrm{~h}$ at room temperature. The reaction was sequentially washed with an aqueous $\mathrm{Na}_{2} \mathrm{CO}_{3}$ solution and brine, and then concentrated. The resultant residue $\mathbf{6}$ was thoroughly dried, and then dissolved in anhyd. THF $(30 \mathrm{ml})$. While vigorously stirring the mixture, $\mathrm{CH}_{3} \mathrm{MgBr}(1.02 \mathrm{M} \mathrm{THF}, 30 \mathrm{ml}, 30.6 \mathrm{mmol})$ was added. The reaction mixture was refluxed for $18 \mathrm{~h}$, the temperature was lowered to room temperature, and the mixture was poured into ice-water containing $\mathrm{NH}_{4} \mathrm{Cl}$. The mixture was extracted with $\mathrm{CHCl}_{3}$, and the organic layer was washed with saturated brine, dried over $\mathrm{Na}_{2} \mathrm{SO}_{4}$, and concentrated under reduced pressure. The residue 7 was refluxed at $70^{\circ} \mathrm{C}$ for $2 \mathrm{~h}$ in a mixture of acetone $(80 \mathrm{ml})$ and an aqueous $5 \% \mathrm{KHSO}_{4}$ solution $(40 \mathrm{ml})$. The organic layer was evaporated, and the residue was reextracted with $\mathrm{CHCl}_{3}$. The $\mathrm{CHCl}_{3}$ layer was washed with saturated brine, dried over $\mathrm{Na}_{2} \mathrm{SO}_{4}$, and concentrated under reduced pressure. Subsequently, the residue 8 was stirred for $2 \mathrm{~h}$ in a mixture of $0.05 \mathrm{~N}$ $\mathrm{NaOH}(100 \mathrm{ml})$ and $\mathrm{MeOH}(100 \mathrm{ml})$ at room temperature. Structures of crude compounds $\mathbf{5}-\mathbf{8}$ were supported by the detection of main signals in ${ }^{1} \mathrm{H}-\mathrm{NMR}$ spectra, respectively. AcOH $(1 \mathrm{ml})$ was added to the reaction mixture, and the mixture was concentrated under reduced pressure to $c a$. half volume. Extraction was performed with $\mathrm{CHCl}_{3}$. The $\mathrm{CHCl}_{3}$ layer was washed with brine, dried over $\mathrm{Na}_{2} \mathrm{SO}_{4}$, and concentrated under reduced pressure. The residue was subjected to column chromatography (silica gel, $70 \mathrm{~g}$ ) using $30 \% \mathrm{EtOAc} / \mathrm{hexane}$ as eluant to give the title compound $9(23 \%$ from compound 4, mp $221-225^{\circ} \mathrm{C}$ (EtOAc). ${ }^{1} \mathrm{H}-\mathrm{NMR}\left(\mathrm{CDCl}_{3}\right): \delta 1.03(3 \mathrm{H}, \mathrm{s})$, $1.05(3 \mathrm{H}, \mathrm{s}), 1.06(3 \mathrm{H}, \mathrm{d}, J=7.33 \mathrm{~Hz}), 1.27(3 \mathrm{H}, \mathrm{d}, J=7.57 \mathrm{~Hz}), 1.42(3 \mathrm{H}, \mathrm{s})$, $1.50(3 \mathrm{H}, \mathrm{s}), 2.29(3 \mathrm{H}, \mathrm{s}), 2.30(3 \mathrm{H}, \mathrm{s}), 2.68-2.71(2 \mathrm{H}, \mathrm{m}), 3.48(1 \mathrm{H}, \mathrm{q}$, $J=7.01 \mathrm{~Hz}), 4.47(1 \mathrm{H}, \mathrm{d}, J=2.43 \mathrm{~Hz}), 5.73(1 \mathrm{H}, \mathrm{s}) . \mathrm{MS}: m / z: 360\left(\mathrm{M}^{+}\right)$ Anal. Calcd for $\mathrm{C}_{22} \mathrm{H}_{32} \mathrm{O}_{4}: \mathrm{C}, 73.30 ; \mathrm{H}, 8.95$. Found: C, 73.40; $\mathrm{H}, 8.99$.

$9 \alpha$-Fluoro-17 $\alpha$-hydroxy-6-methyl-4-pregnene-3,20-dione (10) Нydrogen fluoride-pyridine $[4 \mathrm{ml}, \mathrm{HF}:$ pyridine $=7: 3(\mathrm{w} / \mathrm{w}), 0.14 \mathrm{~mol}]$ was placed in a Teflon container. While maintaining the exterior temperature at $-15^{\circ} \mathrm{C}$, under nitrogen, $11 \beta$-hydroxy-4-pergnane-3,20-dione $9(200 \mathrm{mg}$, $0.55 \mathrm{mmol}$ ) was added. The mixture was stirred for $60 \mathrm{~h}$ at the same temperature, and the mixture was sequentially washed with $3 \% \mathrm{HCl}, 5 \% \mathrm{NaHCO}_{3}$, and brine, dried over $\mathrm{Na}_{2} \mathrm{SO}_{4}$, and concentrated under reduced pressure. The residue was subjected to column chromatography (silica gel, $30 \mathrm{~g}$ ) using $30 \% \mathrm{EtOAc} /$ hexane as eluant to give the fluorinated compound $10(47 \mathrm{mg}$, 23.3\%), mp 232-235 ${ }^{\circ} \mathrm{C}$ (EtOAc). ${ }^{1} \mathrm{H}-\mathrm{NMR}\left(\mathrm{CDCl}_{3}\right): \delta 0.75(3 \mathrm{H}, \mathrm{s}), 0.78$ $(3 \mathrm{H}, \mathrm{s}), 1.11(3 \mathrm{H}, \mathrm{d}, J=6.35 \mathrm{~Hz}), 1.20(3 \mathrm{H}, \mathrm{d}, J=4.96), 1.30(3 \mathrm{H}, \mathrm{s}), 1.37$ $(3 \mathrm{H}, \mathrm{s}), 2.27(3 \mathrm{H}, \mathrm{s}), 2.28(3 \mathrm{H}, \mathrm{s}), 2.69-2.75(2 \mathrm{H}, \mathrm{m}), 2.99-3.07(1 \mathrm{H}, \mathrm{m})$, $3.82(1 \mathrm{H}, \mathrm{d}, J=1.84 \mathrm{~Hz}), 5.85(1 \mathrm{H}, \mathrm{d}, J=3.09 \mathrm{~Hz}), 5.90(1 \mathrm{H}, \mathrm{d}, J=2.00 \mathrm{~Hz})$. MS $m / z: 225\left(\mathrm{M}^{+}\right)$. Anal. Calcd for $\mathrm{C}_{22} \mathrm{H}_{31} \mathrm{O}_{3} \mathrm{~F}: \mathrm{C}, 72.89 ; \mathrm{H}, 8.62$. Found: $\mathrm{C}$, $72.95 ; \mathrm{H}, 8.75$.

9 $\alpha$-Fluoro-17 $\alpha$-hydroxy-6 $\alpha$-methyl-4-pregnene-3,20-dione (12) The 6-methylpregnene $10(40 \mathrm{mg}, 0.11 \mathrm{mmol})$, ethylene glycol $(0.014 \mathrm{ml}$, $0.25 \mathrm{mmol})$, and $p$-TsOH $(2 \mathrm{mg}, 0.01 \mathrm{mmol})$ were added to benzene $(20 \mathrm{ml})$, and refluxed with heat for $3 \mathrm{~h}$ using a reflux condenser equipped with a moisture separator. The solvent was concentrated under reduced pressure, and the residue was combined with an aqueous $5 \% \mathrm{KHSO}_{4}$ solution $(5 \mathrm{ml})$ and acetone $(5 \mathrm{ml})$. The mixture was refluxed for $2 \mathrm{~h}$ at $70{ }^{\circ} \mathrm{C}$. The reaction mixture was concentrated under reduced pressure, and then the residue was extracted with $\mathrm{CHCl}_{3}$. The $\mathrm{CHCl}_{3}$ layer was washed with saturated brine, 
dried over $\mathrm{Na}_{2} \mathrm{SO}_{4}$, and concentrated under reduced pressure. The residue was subjected to column chromatography (silica gel, $20 \mathrm{~g}$ ) using 30\% EtOAc/hexane as eluant to give the methylated derivative $\mathbf{1 2}(23 \mathrm{mg}, 57.5 \%$ from compound 10), $\mathrm{mp} 237-239^{\circ} \mathrm{C}$ (EtOAc). $[\alpha]_{\mathrm{D}}^{27}+23.76^{\circ}(c=0.202$, $\mathrm{MeOH}) .{ }^{1} \mathrm{H}-\mathrm{NMR}\left(\mathrm{CDCl}_{3}\right): \delta 0.86(3 \mathrm{H}, \mathrm{s}), 1.10(3 \mathrm{H}, \mathrm{d}, J=6.45 \mathrm{~Hz}), 1.30$ $(3 \mathrm{H}, \mathrm{s}), 2.69-2.79(2 \mathrm{H}, \mathrm{m}), 2.99-3.03(1 \mathrm{H}, \mathrm{m}), 3.84(1 \mathrm{H}, \mathrm{d}, J=1.80 \mathrm{~Hz})$, $5.89(1 \mathrm{H}, \mathrm{d}, J=1.80 \mathrm{~Hz})$. MS $m / z: 362\left(\mathrm{M}^{+}\right)$. Anal. Calcd for $\mathrm{C}_{22} \mathrm{H}_{31} \mathrm{O}_{3} \mathrm{~F}: \mathrm{C}$, 72.89; H, 8.62. Found: C, 72.90; H, 8.78.

$17 \alpha$-Acetoxy- $9 \alpha$-fluoro- $6 \alpha$-methylprogesterone (1) $9 \alpha$-Fluoromedroxyprogesterone $12(20 \mathrm{mg}, 0.055 \mathrm{mmol})$ was stirred for $5 \mathrm{~h}$ at $-10{ }^{\circ} \mathrm{C}$ in the presence of $p$ - TsOH $(20 \mathrm{mg}, 0.11 \mathrm{mmol}), \mathrm{Ac}_{2} \mathrm{O}(0.4 \mathrm{ml}, 4.23 \mathrm{mmol})$, and $\mathrm{CH}_{2} \mathrm{Cl}_{2}(1 \mathrm{ml})$ under nitrogen. Water $(10 \mathrm{ml})$ was added to the reaction mixture, and extraction was performed with $\mathrm{CHCl}_{3}$. The $\mathrm{CHCl}_{3}$ layer was washed with an aqueous $5 \% \mathrm{NaHCO}_{3}$ solution and saturated brine, dried over $\mathrm{Na}_{2} \mathrm{SO}_{4}$, and concentrated under reduced pressure. The residue was subjected to column chromatography (silica gel, 20 g) using 30\% EtOAc/hexane as eluant to give the $17 \alpha$-acetoxy- $9 \alpha$-fluoro- $6 \alpha$-methylprogesterone (1) $(8 \mathrm{mg}, 36 \%), \mathrm{mp} 208-210^{\circ} \mathrm{C}$ (EtOAc). $[\alpha]_{\mathrm{D}}^{20}+36.0^{\circ}(c=0.210$, $\left.\mathrm{CHCl}_{3}\right)$. IR (KBr) cm ${ }^{-1}: 1742,1709,1674 .{ }^{1} \mathrm{H}-\mathrm{NMR}\left(500 \mathrm{MHz}, \mathrm{CDCl}_{3}\right): \delta$ $0.68(3 \mathrm{H}, \mathrm{s}), 1.12(3 \mathrm{H}, \mathrm{d}, J=6.5 \mathrm{~Hz}), 1.31(3 \mathrm{H}, \mathrm{s}), 2.05(3 \mathrm{H}, \mathrm{s}), 2.10(3 \mathrm{H}, \mathrm{s})$, $2.96(1 \mathrm{H}$, ddd, $J=2.5,11.3,14.3 \mathrm{~Hz}), 5.90(1 \mathrm{H}, \mathrm{d}, J=1.5 \mathrm{~Hz}) .{ }^{13} \mathrm{C}-\mathrm{NMR}$ $\left(125 \mathrm{MHz}, \mathrm{CDCl}_{3}\right) \delta: 13.3,17.9,21.1,21.3,23.6,25.0,26.2,26.8,29.1$, 30.3, 33.1, 33.6, 34.4, 37.6, 43.3, 44.6, 46.1, 96.2, 99.4, 123.9, 169.8, 170.6, 198.7, 203.6. MS $m / z: 404\left(\mathrm{M}^{+}\right)$. HR-MS $m / z: 404.2380$ (Calcd for $\left.\mathrm{C}_{24} \mathrm{H}_{33} \mathrm{O}_{4} \mathrm{~F}: 404.2361\right)$.

$17 \alpha$-Acetoxy-11 $\beta, 21$-dihydroxy- $6 \alpha$-methyl-1,4-pregnadiene-3,20dione (14) Pyridinium $p$-toluenesulfonate $(28.0 \mathrm{mg}, 0.11 \mathrm{mmol})$ and trimethyl orthoacetate $(1.01 \mathrm{ml}, 7.94 \mathrm{mmol})$ were added to a solution $(60 \mathrm{ml})$ of $6 \alpha$-methylpredonisolone ( $6 \alpha$-methyl-11 $\beta, 17 \alpha, 21$-trihydroxy-1,4-pregnadiene-3,20-dione) $13(2.13 \mathrm{~g}, 5.69 \mathrm{mmol})$ in $\mathrm{CH}_{2} \mathrm{Cl}_{2}$. The mixture was stirred at room temperature $\left(20-25^{\circ} \mathrm{C}\right)$ for $5 \mathrm{~h}$. When the reaction was completed, the reaction mixture was concentrated under reduced pressure. The residue was dissolved in acetone $(30 \mathrm{ml})$. While cooling the mixture on ice, an aqueous solution $(30 \mathrm{ml})$ of $p-\mathrm{TsOH}(1.19 \mathrm{~g}, 6.26 \mathrm{mmol})$ was added thereto. The mixture was stirred for $30 \mathrm{~min}$ on ice. Upon completion of reaction, a saturated aqueous $\mathrm{NaHCO}_{3}$ solution was added and extraction was performed with EtOAc. The EtOAc layer was washed with brine, dried over $\mathrm{Na}_{2} \mathrm{SO}_{4}$, and concentrated under reduced pressure. The residue was purified by column chromatography (silica gel, $40 \mathrm{~g}$ ) using $50 \%$ EtOAc/hexane as eluant to give $17 \alpha$-acetoxy-11 $\beta, 21$-dihydroxy- $6 \alpha$-methyl-1,4-pregnadiene3,20-dione $14(2.11 \mathrm{~g}, 89 \%), \mathrm{mp} 159-161^{\circ} \mathrm{C}$ (EtOAc). $[\alpha]_{\mathrm{D}}^{20}+18.1^{\circ}$ $\left(c=0.490, \mathrm{CHCl}_{3}\right) .{ }^{1} \mathrm{H}-\mathrm{NMR}\left(500 \mathrm{MHz}, \mathrm{CDCl}_{3}\right) \delta: 0.97(3 \mathrm{H}, \mathrm{s}), 1.13(3 \mathrm{H}, \mathrm{d}$, $J=6.0 \mathrm{~Hz}), 1.46(3 \mathrm{H}, \mathrm{s}), 2.02(3 \mathrm{H}, \mathrm{s}), 2.74-2.82(1 \mathrm{H}, \mathrm{m}), 4.24(1 \mathrm{H}, \mathrm{dd}$ $J=4.0,18.0 \mathrm{~Hz}), 4.33(1 \mathrm{H}, \mathrm{dd}, J=3.5,18.0 \mathrm{~Hz}), 6.04(1 \mathrm{H}, \mathrm{s}), 6.28(1 \mathrm{H}, \mathrm{d}$, $J=10.0 \mathrm{~Hz}), 7.25(1 \mathrm{H}, \mathrm{d}, J=10.0 \mathrm{~Hz})$. MS $m / z: 416\left(\mathrm{M}^{+}\right)$. Anal. Calcd for $\mathrm{C}_{24} \mathrm{H}_{32} \mathrm{O}_{6}$ : C, 69.21; H, 7.74. Found: C, 69.08; H, 7.80.

$17 \alpha$-Acetoxy-11 $\beta$-hydroxy- $6 \alpha$-methyl-1,4-pregnadiene-3,20-dione (15) Methanesulfonyl chloride ( $\mathrm{MsCl})(0.15 \mathrm{ml}, 1.94 \mathrm{mmol})$ was added to a solution of $17 \alpha$-acetoxy-11 $\beta, 21$-dihydroxy- $6 \alpha$-methyl-1,4-pregnadiene-3,20dione $14(557 \mathrm{mg}, 1.34 \mathrm{mmol})$ in pyridine $(10 \mathrm{ml})$. The mixture was stirred at between 0 and $5{ }^{\circ} \mathrm{C}$ (external temperature) for $3 \mathrm{~h}$. After completion of reaction, iced water and ethyl acetate were added to the reaction mixture. The resultant mixture was sequentially washed with $10 \% \mathrm{HCl}$, a saturated aqueous $\mathrm{NaHCO}_{3}$ solution, and brine, and then dried over $\mathrm{Na}_{2} \mathrm{SO}_{4}$. After the sol0vent was evaporated under reduced pressure, the residue was dissolved in pyridine $(10 \mathrm{ml})$. Sodium iodide $(447 \mathrm{mg}, 2.98 \mathrm{mmol})$ was added to the solution, and the mixture was refluxed for $50 \mathrm{~min}$. Upon completion of the reaction, a saturated aqueous $\mathrm{Na}_{2} \mathrm{SO}_{3}$ solution was added to the reaction mixture, and then extraction was performed with EtOAc. The EtOAc layer was washed with $10 \% \mathrm{HCl}$, a saturated aqueous $\mathrm{NaHCO}_{3}$ solution, saturated brine, and dried over $\mathrm{Na}_{2} \mathrm{SO}_{4}$. The organic layer was evaporated under reduced pressure. The residue was subjected to silica gel column chromatography (silica gel, $16 \mathrm{~g}$ ) using $50 \%$ EtOAc/hexane as eluant to give $17 \alpha$ acetoxy-11 $\beta$-hydroxy- $6 \alpha$-methyl-1,4-pregnadiene-3,20-dione 15 (316 mg, $59 \%), \mathrm{mp} 138-140^{\circ} \mathrm{C}$ (EtOAc). $[\alpha]_{\mathrm{D}}^{20}+13.2^{\circ}\left(c=0.430, \mathrm{CHCl}_{3}\right) .{ }^{1} \mathrm{H}-\mathrm{NMR}$ $\left(500 \mathrm{MHz}, \mathrm{CDCl}_{3}\right) \delta: 0.95(3 \mathrm{H}, \mathrm{s}), 1.13(3 \mathrm{H}, \mathrm{d}, J=6.5 \mathrm{~Hz}), 1.46(3 \mathrm{H}, \mathrm{s})$, $2.06(3 \mathrm{H}, \mathrm{s}), 2.05(3 \mathrm{H}, \mathrm{s}), 2.90-2.98(1 \mathrm{H}, \mathrm{m}), 6.05(1 \mathrm{H}, \mathrm{t}, J=2.0 \mathrm{~Hz}), 6.29$ $(1 \mathrm{H}, \mathrm{dd}, J=2.0,10.0 \mathrm{~Hz}), 7.25(1 \mathrm{H}, \mathrm{d}, J=10.0 \mathrm{~Hz})$. MS $m / z: 400\left(\mathrm{M}^{+}\right)$. Anal. Calcd for $\mathrm{C}_{24} \mathrm{H}_{32} \mathrm{O}_{5}$ : C, 71.97; $\mathrm{H}, 8.05$. Found: $\mathrm{C}, 72.04 ; \mathrm{H}, 8.11$.
$17 \alpha$-Acetoxy-11 $\beta$-hydroxy-6 $\alpha$-methyl-4-pregnene-3,20-dione

Chlorotris(triphenylphosphine)rhodium(I) $(8.51 \mathrm{mg}, 9.20 \mu \mathrm{mol})$ was added to a solution of $17 \alpha$-acetoxy-11 $\beta$-hydroxy- $6 \alpha$-methyl-1,4-pregnadiene-3,20dione $15(316 \mathrm{mg}, 0.79 \mathrm{mmol})$ in $\mathrm{CH}_{2} \mathrm{Cl}_{2}-\mathrm{EtOH}(1: 1 ; 30 \mathrm{ml})$. The mixture was stirred for $27 \mathrm{~h}$ at room temperature $\left(20-25^{\circ} \mathrm{C}\right)$ in a stream of hydrogen gas $\left(1.5 \mathrm{~kg} / \mathrm{cm}^{2}\right)$. After completion of reaction, the reaction mixture was concentrated under reduced pressure. The residue was subjected to silica gel column chromatography (silica gel, $10 \mathrm{~g}$ ) using 50\% EtOAc/hexane as eluant to give $17 \alpha$-acetoxy-11 $\beta$-hydroxy- $6 \alpha$-methyl-4-pregnene-3,20-dione $\mathbf{1 6}$ (285 mg, 90\%), mp 193-195 ${ }^{\circ} \mathrm{C}$ (EtOAc). $[\alpha]_{\mathrm{D}}^{20}+55.4^{\circ}\left(c=0.773, \mathrm{CHCl}_{3}\right)$. ${ }^{1} \mathrm{H}-\mathrm{NMR}\left(500 \mathrm{MHz}, \mathrm{CDCl}_{3}\right) \delta: 0.93(3 \mathrm{H}, \mathrm{s}), 1.06(3 \mathrm{H}, \mathrm{d}, J=6.5 \mathrm{~Hz}), 1.43$ $(3 \mathrm{H}, \mathrm{s}), 2.06(3 \mathrm{H}, \mathrm{s}), 2.07(3 \mathrm{H}, \mathrm{s}), 2.92-2.98(1 \mathrm{H}, \mathrm{m}), 5.73(1 \mathrm{H}, \mathrm{d}$, $J=1.5 \mathrm{~Hz})$. MS $m / z: 402\left(\mathrm{M}^{+}\right)$. Anal. Calcd for $\mathrm{C}_{24} \mathrm{H}_{34} \mathrm{O}_{5}: \mathrm{C}, 71.61 ; \mathrm{H}, 8.51$. Found: $\mathrm{C}, 71.75 ; \mathrm{H}, 8.53$.

$17 \alpha$-Acetoxy-9 $\alpha$-fluoro-6 $\alpha$-methylprogesterone (1) Hydrogen fluoride-pyridine $[4 \mathrm{ml}, \mathrm{HF}:$ pyridine $=7: 3(\mathrm{w} / \mathrm{w}), 0.14 \mathrm{~mol}]$ was placed in a Teflon container. While maintaining the exterior temperature at $-15^{\circ} \mathrm{C}$, under nitrogen, $17 \alpha$-acetoxy-11 $\beta$-hydroxy- $6 \alpha$-methyl-4-pregnene-3,20dione $16(145 \mathrm{mg}, 0.36 \mathrm{mmol})$ was added. The solution was stirred for $65 \mathrm{~h}$ at the same external temperature of $-15^{\circ} \mathrm{C}$. When the reaction was completed, ice water was added to the reaction mixture, which was then extracted with EtOAc $(50 \mathrm{ml}, 30 \mathrm{ml})$. The organic layer was sequentially washed with $10 \% \mathrm{HCl}$, saturated $\mathrm{NaHCO}_{3}$, and brine, and then dried over $\mathrm{Na}_{2} \mathrm{SO}_{4}$. After the solvent was evaporated under reduced pressure, the residue was subjected to column chromatography (silica gel, $6 \mathrm{~g}$ ) using $40 \%$ EtOAc/hexane as eluant to give $17 \alpha$-acetoxy- $9 \alpha$-fluoro- $6 \alpha$-methylprogesterone (1) $(37.9 \mathrm{mg}, 26 \%)$, which was identical with the FMPA synthesized previously in all respects.

Anti-tumor Effect on Rat Mammary Carcinoma The following animal studies were performed in accordance with the Guiding Principles for the Care and Use of Laboratory Animals approved by the Japanese Pharmacological Society. DMBA was administered orally at a single dose of $20 \mathrm{mg} /$ body to female Sprague-Dawley rats about 50 days old. When the diameter of the first developed mammary tumor became $0.5-1.5 \mathrm{~cm} 8-12$ weeks after DMBA administration, the animal was incorporated into the study. FMPA (1), complexed with DM- $\beta$-CyD, was administered to the animals orally once a day at doses of 30 and $120 \mathrm{mg} / \mathrm{kg} /$ day for 3 weeks. Distilled water and DM- $\beta$-CyD $(498 \mathrm{mg} / \mathrm{ml})$ were administered to the animals orally once a day at a volume of $6 \mathrm{ml} / \mathrm{kg} /$ day for 3 weeks. The two largest perpendicular diameters of each tumor were measured on the first day of treatment and thereafter once a week for 6 weeks. The multiplied product of these diameters was expressed as tumor size. Number of tumors per rat appeared after treatment was also counted.

Acknowledgments We would like to thank Professor Kazuhiko Saigo for helpful discussions.

\section{References}

1) Battegay E. J., J. Mol. Med., 73, 333-346 (1995).

2) Votruba M., Gregor Z., Eye, 15, 424-429 (2001).

3) Folkman J., Shing Y., J. Biol. Chem., 267, 10931-10934 (1992).

4) Sugino E., Fujimori S., Hibino S., Choshi T., Ichihara Y., Sato Y., Yamaji T., Tsuboi H., Murata N., Uchida M., Shimamura M., Oikawa T., Chem. Pharm. Bull., 45, 421—423 (1997).

5) Uchida M., Tsuboi H., Yamaji T., Murata N., Kohno T., Sugino E., Hibino S., Shimamura M., Oikawa T., Cancer Lett., 154, 63-69 (2000).

6) Yamaji T., Tsuboi H., Murata N., Uchida M., Kohno T., Sugino E., Hibino S., Shimamura M., Oikawa T., Cancer Lett., 145, 107-114 (1999).

7) Bergstrom C. G., Dodson R. M., J. Am. Chem. Soc., 82, 3479-3480 (1960).

8) Fried J. H., Arth G. E., Sarett L. H., J. Am. Chem. Soc., 81, 12351239 (1959).

9) Carruthers N. I., Garshasb S., J. Org. Chem., 57, 961-965 (1992).

10) Djerassi C., Gutzwiller J., J. Am. Chem. Soc., 88, 4537-4538 (1966).

11) Kozutsumi D., Kawashima A., Sugimoto T., Kotohda Y., Fujimori S., Takami M., Kohno T., Oikawa T., Sugino E., Choshi T., Hibino S., Biopharm. Drug Dispos., 20, 277-284 (1999). 